\title{
S100P Gene
}

National Cancer Institute

\section{Source}

National Cancer Institute. S100P Gene. NCI Thesaurus. Code C24763.

This gene plays a regulatory role in several cellular processes, and mediates calciumbinding interactions. 